\title{
Sea turtle bycatch and consumption in Egypt threatens Mediterranean turtle populations
}

\author{
Mohamed Nada and Pa olo Casale
}

\begin{abstract}
Turtle trade in the fish markets of Alexandria was reported up to the late 1990s, motivating conservation initiatives and enforcement of legal protection. To assess the current trade and bycatch levels in Alexandria and other ports we carried out an interview survey of 445 people in 2007, mostly fishermen and fishmongers, in 15 coastal cities and fishing ports along the Mediterranean coast of Egypt. The declared catch rates and official fishing fleet statistics suggest that captures of loggerhead Caretta caretta and green turtles Chelonia mydas are in the order of several thousands per year, possibly $>7,000$ per year, mainly from trawling, longlining and set nets. Probably several hundred turtles die each year as a consequence of the high mortality rates typical of these fishing gears. In addition, most fishermen from Alexandria and some fishermen from other regions declared that they kill turtles for meat. Regulations and enforcement appear to be ineffective, as turtles are usually killed and consumed on board or only their meat is landed. Some turtles are still traded on the black market in some Alexandria fish markets. The overall mortality probably represents an unsustainable toll on the Mediterranean loggerhead and green turtle populations, and the perception of fishermen is that turtle numbers are declining. Mitigating the identified threats is thus urgent. In particular, intentional killing should be tackled through its cultural drivers, and measures to reduce bycatch mortality need to be tested and implemented.
\end{abstract}

Keywords Bycatch, Caretta caretta, Chelonia mydas, consumption, Egypt, Mediterranean Sea, sea turtles, trade

\section{Introduction}

arine turtles have represented nutritional, economic 1 and spiritual resources to many human communities for at least 7,000 years (see Frazier, 2003, for a review). Among these possible uses, consumption is predominant. It was widely practised (Campbell, 2003; Frazier, 2003) and associated with the traditional and cultural heritage of various communities (Cliffton et al., 1982; Figueroa et al., 1992). From the 17th century onwards marine turtle con-

Mohamed Nada Mohandiseen, Giza, Egypt

PaOlo Casale (Corresponding author) WWF Mediterranean Marine Turtle Programme c/o WWF Italy, Via Po 25c, 00198 Rome, Italy, and Department of Biology and Biotechnology "Charles Darwin", University of Rome "La Sapienza”, Viale dell'Università 32, 00185 Rome, Italy. E-mail p.casale@wwf.it

Received 8 July 2009. Revision requested 5 October 2009.

Accepted 6 February 2010. sumption increased because of factors such as the increase in the human population, increased fishing and capture capacity, and more efficient trade that responded to wider market demand (National Research Council, 1990; Lutcavage et al., 1997; Fleming, 2001; Campbell, 2003). Turtle trade is a major factor driving declines of marine turtle populations (Fleming, 2001), and six of the seven extant marine turtle species are categorized as threatened on the IUCN Red List (IUCN, 2010). Consumption of, and trade in, marine turtles were banned or regulated through several international conventions and national legislation (Wold, 2002; Campbell et al., 2009). Nevertheless, consumption of turtle meat and eggs still occurs, legally or not, in many places (Fleming, 2001; Campbell, 2003; Mancini \& Koch, 2009). Capture by fishing gear, however, has become a major threat to marine turtle populations (Lutcavage et al., 1997) because of the general increase in fishing effort, and is a serious conservation challenge for marine magafauna in general (Lewison et al., 2004; Soykan et al., 2008).

In the Mediterranean Sea fishing is severely affecting ecosystems (Tudela, 2004; Sacchi, 2008) and is a major threat for large vertebrates of conservation concern such as sharks (Ferretti et al., 2008), cetaceans (Bearzi, 2002), monk seals (Karamanlidis et al., 2008) and marine turtles (Casale, 2008). Two species of marine turtles have populations in the Mediterranean, the loggerhead turtle Caretta caretta and the green turtle Chelonia mydas; the latter has a relatively small population restricted to the easternmost Mediterranean (Broderick et al., 2002).

Egypt was one of the first markets to trade in marine turtles in the Mediterranean Sea: both loggerhead and green turtles have been sold in several fish markets along the Mediterranean coast (Alexandria, Abou Keer, Brullos, Port Said and Damietta) since at least the beginning of the 2oth century (Laurent et al., 1996, and references therein). Probably most of these turtles were captured off Cyprus, Turkey and Palestine, transported to Egypt and then to Europe (Laurent et al., 1996, and references therein). Since the 1970 s turtle consumption has been an established tradition in some places in Egypt and, in 1992, official records of landings of marine turtles on the Mediterranean coast of Egypt totalled $231 \mathrm{t}$ (Laurent et al., 1996).

Egypt is a signatory of several conventions for nature conservation and several national regulations that cover marine turtles were issued in the 1980s and 1990s. The most important is the Environmental Law 4/1994, which states that 'killing, capturing, transportation, selling, nest destruction and display of an endangered species either dead or alive 
is prohibited when Egypt is signatory to an International Convention'. However, in spite of this regulation, egg consumption was observed in 1998 (Clarke et al., 2000) and trade in marine turtle meat and blood in Alexandria fish markets went on at least until 1999, with 18-25 turtles slaughtered per week in the Anfoushi fish market (Laurent et al., 1996; Nada, 2001). The government increased the enforcement of laws in the Alexandria fish markets in 1999 (Venizelos \& Nada, 2000) but the present situation is unknown, as is the number of turtles caught by Egyptian fishing boats on the Mediterranean coast, although Laurent et al. (1996) suggested that a high number was caught by trawlers alone.

This bycatch and the associated illegal turtle trade probably affect several marine turtle populations in the Mediterranean. Satellite tracking of nesting females has shown that Egyptian waters are foraging grounds and migratory corridors for green turtles originating from Cyprus and Syria (Broderick et al., 2007; Rees et al., 2008a), two of the three nesting areas for this species in the Mediterranean (Kasparek et al., 2001; Rees et al., 2008b). Nesting loggerhead turtle females have been tracked from Cyprus to Egypt (Broderick et al., 2007) and genetic markers indicate that loggerhead turtles found in Egypt also originate from Turkey and, possibly, Greece (Casale et al., 2008a), which represent most of the major nesting grounds for this species (Margaritoulis et al., 2003). There are no data available regarding potential use of Egyptian foraging grounds by turtles from the other two major marine turtle nesting areas in the Mediterranean, i.e. green turtle rookeries in Turkey and loggerhead turtle rookeries in Libya. Egyptian waters are thus an area of concern for the conservation of marine turtles in the Mediterranean (Laurent et al., 1996; Margaritoulis et al., 2003; WWF, 2005).

This study provides an assessment of the threats to marine turtle populations along the Mediterranean coast of Egypt using information collected by interviews. Although this implies an intrinsic degree of uncertainty, we assess the current level of marine turtle consumption and trade in Alexandria and the potential trade in other areas, estimate the magnitude of bycatch, and assess the effectiveness of conservation actions undertaken so far.

\section{Methods}

Field surveys were carried out during June-October 2007 in the 15 most important fishing ports along the Egyptian Mediterranean coast, in four regions (Fig. 1). This division follows the common geographical division of Mediterranean Egypt, which has also been adopted for other surveys (Clarke et al., 2000).

A total of 445 people were interviewed by $\mathrm{MN}$. The interviewees were selected by convenience sampling (Kelley et al., 2003), i.e. persons encountered by chance at

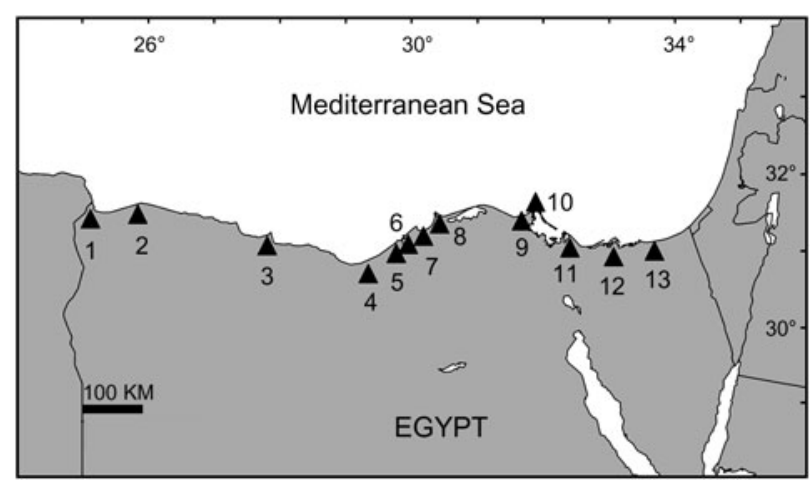

FIG. 1 The Mediterranean coast of Egypt with the 13 places where surveys were carried out. Western Region: 1, El Salum; 2, Sidi Barani; 3, Marsa Matruh; 4, El Hamam; 5, Alexandria Governorate (El Max, Anfoushi, Abou Keer); Central or Delta Region: 6, El Maadiya; 7, Edco; 8, Rousata; 9, Azzbat El Borg; 10, Domiat; Eastern or Sinai Region: 11, Port Said; 12, Lake Bardawil; 13, Areash.

the place and time of the survey, and all the people approached accepted to be interviewed. Although this was not a random sample from the statistical populations of target groups, the occurrence of interviewees at the time of the survey was assumed not to be associated with a bias in the information asked; i.e. the interviewees were assumed to be representative of their population. Interviewees were informed that (1) the only purpose of the interview was to collect information on the status and biology of marine turtles in the Mediterranean Sea and their interaction with fishermen and local communities, (2) they could retain any information that they did not wish to share, and (3) their names were not required and would not be recorded.

One set of interviews included 219 fishermen, 88 fishmongers and 92 members (61 male and 31 female) of local communities. The main questions asked (directly or indirectly) were (1) Which type of fishing gear do you use? (2) Do you capture turtles? (3) Do you kill turtles? (4) If yes, why? (5) Do you sell turtles to someone else? (6) Are you aware that killing turtles is illegal? How do you deal with this? (7) On average, how many turtles do you capture per year? (8) With which fishing gear? (9) On the basis of your experience, are turtles increasing, stable or decreasing? (10) Which species of turtles do you catch or see?

Another set of interviews were conducted with key stakeholders in various government and non-government institutions: 32 governmental officers (four at the national level and 28 at the community level) and 14 representatives of six NGOs. They were asked about their knowledge of the turtle trade and the protection status of sea turtles. In addition, 14 focus groups (seven with fishermen, two with fishmongers, four with members of local communities and one with the police officers mandated to oversee the conservation of marine turtles in Alexandria fishing port), 
Rapid Rural Appraisal (Crawford, 1997; discussing whilst walking and with local people, paying specific attention to people, activities, resources and environmental features) and life history exercises (collection of detailed life and work histories) were conducted with local communities.

\section{Results}

The fishermen interviewed were able to distinguish the three marine turtle species occurring in Egypt (loggerhead and green turtles, and leatherback turtle Dermochelys coriacea). Fishermen from Alexandria have names for two species and these imply that green turtles (balady, national species, referring by this to its authentic taste) have a better taste than loggerhead turtles (gashawy, fake turtle). Fishermen from all regions reported that they catch all three species, although loggerhead turtles are the most common, followed by green turtles, and leatherback turtles are rare. From the descriptions provided by the fishermen, most of the turtles they captured were large juveniles or adults.

According to $89 \%$ of the 219 fishermen the number of turtles is decreasing, $8.2 \%$ of them did not perceive any change and $2.7 \%$ stated turtles are increasing (Table 1). Fishermen of the Western Region attributed decreases in turtles mainly to bycatch. Fishermen in Alexandria attributed declines to killing for consumption, bycatch and pollution (because they often found plastic bags in the digestive tract of turtles). Fishermen of the Central Region believed that the decline is mainly because of bycatch and pollution. In the Eastern Region fishermen stated that the main reasons are bycatch, consumption and pollution (Table 2) and they also mentioned destruction of nesting sites as an important factor.

With the exception of purse seines fishermen declared similar bycatch rates of turtles by various fishing gears (Table 3). However, this could be partially because of fishermen's inability to remember with which fishing gear they caught a specific turtle, because most fishermen use a variety of gears during the same year, depending on the season and the target species. On the basis of these catch rates and on fishery statistics (Table 3) we estimate the annual total number of turtles caught along the Mediter-

TABLE 1 Percentages (by row) of the 219 fishermen interviewed who perceived turtle abundance to be decreasing, stable or increasing, by region and overall.

\begin{tabular}{llclc}
\hline Region & $\begin{array}{l}\text { Decreasing } \\
(\%)\end{array}$ & $\begin{array}{l}\text { Stable } \\
(\%)\end{array}$ & $\begin{array}{l}\text { Increasing } \\
(\%)\end{array}$ & $\begin{array}{l}\text { Fishermen } \\
(\mathrm{n})\end{array}$ \\
\hline Western & 78.3 & 17.4 & 4.3 & 23 \\
Alexandria \& & 94.9 & 3.8 & 1.3 & 157 \\
$\quad$ Central & & & & \\
Eastern & 71.8 & 20.5 & 7.7 & 39 \\
Total & 89.0 & 8.2 & 2.7 & 219 \\
\hline
\end{tabular}

ranean coast of Egypt is 7,164 (these are captures, not necessarily individual turtles, because the same turtle can be caught more than once).

The attitude towards marine turtle consumption differed dramatically between the four regions (Table $4 ; \chi^{2}=$ 135.54, $\mathrm{df}=3, \mathrm{P}<0.001, \mathrm{n}=399$ ). Turtle consumption is commonest in the Alexandria Region, with $61.7 \%$ of people interviewed declaring that they ate turtles, compared to $19.7 \%$ in the Eastern Region, 3.7\% in the Central Region and none in the Western Region. The interviews indicated that these differences between regions are cultural. In Alexandria consuming turtle meat and blood is an old tradition, whereas it is seen as a bizarre custom in the Western Region.

Where turtle consumption occurs it is most common amongst fishermen (Table 4). In Alexandria, $77.2 \%$ of the 92 fishermen interviewed reported they have eaten marine turtle meat and $38 \%$ did so at least once in the previous 6 months. They stated that when they catch a marine turtle they slaughter and consume it during the fishing trip. Sometimes, however, they put the meat in plastic bags and throw the carapace and bones in the sea, so that police officers will not be able to identify them. This practice was confirmed by $68.4 \%$ of fishermen interviewed in Alexandria $(\mathrm{n}=92)$.

In Alexandria we did not observe any marine turtles on sale in the public fish markets and $88 \%$ of 24 interviewed police officers inspecting the landing sites were aware that Egyptian law prohibits turtle trade and consumption. They also affirmed they received strict instructions that turtle protection should be enforced. However, $71 \%$ of the 42 fishmongers interviewed indicated that a black market still exists and that smuggling of marine turtles is still taking place. During the survey we found three marine turtles on sale on the black market: an adult female green turtle in El Max, and an adult female loggerhead turtle and a juvenile loggerhead turtle in Anfoushi. We did not find evidence of turtle trade in the other regions. However, four turtles, one in Rousata and three in Domiat, were observed on display in water tanks in fish restaurants, to attract clients.

Of the 23 fishermen interviewed in the Western Region, $20(87 \%)$ mentioned they observed at least one turtle nesting in the previous 10 years, $13(57 \%)$ in the last 3 years and two $(8.7 \%)$ in the last year (2006). All the fishermen interviewed stated that only loggerhead turtles nest in this area. Of the 39 fishermen interviewed in the Eastern Region these figures were 38 (97\%), 35 (89.7\%) and 25 (64.1\%), respectively. These fishermen said that both loggerhead and green turtles nest in this region but that the former is more common. All 157 fishermen interviewed in the Alexandria and Central Regions stated that they have not seen any turtles nesting in the past 10 years. However, three fishermen indicated that some nesting occurred on Alexandria beaches $>30$ years previously. Rangers of the Zaranik protected area (the main marine turtle nesting site along 
TABLE 2 Percentages (by row) of the 219 fishermen interviewed who perceived bycatch, pollution, killing for consumption and beach development to be threats to marine turtles, by region and fishing community.

\begin{tabular}{|c|c|c|c|c|c|}
\hline $\begin{array}{l}\text { Fishing community } \\
\text { (by region) }\end{array}$ & Bycatch (\%) & Pollution (\%) & Consumption (\%) & $\begin{array}{l}\text { Beach } \\
\text { development (\%) }\end{array}$ & Fishermen (n) \\
\hline \multicolumn{6}{|l|}{ Western } \\
\hline El Salum & 75.0 & 12.5 & & 12.5 & 8 \\
\hline Sidi Barani & 83.3 & 16.7 & & & 6 \\
\hline Marsa Matruh & 77.8 & 22.2 & & & 9 \\
\hline \multicolumn{6}{|l|}{ El Hamam } \\
\hline Subtotal & 78.3 & 17.4 & & 4.3 & 23 \\
\hline \multicolumn{6}{|l|}{ Alexandria } \\
\hline El Max & 30.4 & 13.1 & 56.5 & & 23 \\
\hline Anfoushi & 28.6 & 19.0 & 52.4 & & 42 \\
\hline Abou Keer & 25.9 & 22.2 & 51.9 & & 27 \\
\hline Subtotal & 28.3 & 18.5 & 53.2 & & 92 \\
\hline \multicolumn{6}{|l|}{ Central } \\
\hline El Maadiya & 76.9 & 23.1 & & & 13 \\
\hline Edco & 75.0 & 25.0 & & & 12 \\
\hline Rousata & 68.7 & 31.3 & & & 16 \\
\hline Azzbat El Borg & 71.4 & 28.6 & & & 14 \\
\hline Domiat & 60.0 & 40.0 & & & 10 \\
\hline Subtotal & 70.8 & 29.2 & & & 65 \\
\hline \multicolumn{6}{|l|}{ Eastern } \\
\hline Port Said & 68.7 & 25.0 & 6.3 & & 16 \\
\hline Lake Bardawil & 25.0 & 16.7 & 41.6 & 16.7 & 12 \\
\hline Areash & 18.2 & 18.2 & 45.4 & 18.2 & 11 \\
\hline Subtotal & 41.0 & 20.5 & 28.2 & 10.3 & 39 \\
\hline Total & 48.4 & 21.9 & 27.4 & 2.3 & 219 \\
\hline
\end{tabular}

the Mediterranean coast of Egypt, in the Eastern Region; Clarke et al., 2000), confirmed that nesting still occurs there (mostly loggerhead turtles but also green turtles) and they recorded 15 nests in 2007 and 17 in 2006.

\section{Discussion}

Our results show that marine turtles in the Mediterranean region of Egypt are more threatened by human activities than previously thought (Laurent et al., 1996; Nada, 2001) and that the issue of turtle trade has only been partially solved by the conservation actions so far undertaken. Previous surveys reported that high numbers of turtles were traded in the Anfoushi fish market of Alexandria (Laurent et al., 1996; Nada, 2001) but turtles are no longer publicly traded there. The percentage of fishermen and fishmongers who are aware that trading in marine turtles is illegal ( 79 and $85 \%$, respectively) has increased compared to 1999 ( $<30 \%$; Nada, 2001). This is probably because of awareness campaigns by NGOs and increased enforcement of marine turtle protection, with inspections at the Anfoushi fish market and official landing sites. However, in the Anfoushi area turtles are still traded on the black market, and in the Abou Keer fish market of Alexandria marine turtles are still traded publicly according to the interviewed fishmongers. The difference between the An- foushi and Abou Keer markets could be because more enforcement activities and awareness campaigns (Venizelos \& Nada, 2000) have focused on Anfoushi. The Anfoushi fish market has been given increasing attention by the Alexandria Governorate since 2000 because it is in one of the main tourist destinations of Alexandria (M. Nada, pers. obs.). The recent attention to marine turtle conservation is probably because of the establishment of the Egyptian Environmental Affairs Agency (EEAA) and its branch in Alexandria, international pressure on Egypt to protect these species, pressure from national NGOs, and the enhanced capacity on marine turtle issues of a group of government officers who were involved in a survey by research institutes and the EEAA (Clarke et al., 2000).

Our results indicate that marine turtle mortality from intentional killing and consumption by fishermen while out fishing is more important than mortality from trade. Only parts of turtles caught are landed and only some of these are traded in public or black markets. Both on-board killing and landing of turtle meat, which is difficult to recognize as such, easily escape current controls. Turtle consumption by fishermen and local community members is particularly common in Alexandria and occurs to a lesser extent in other regions. Given the high number of turtles estimated to be caught in Egypt (Table 3) and that as a whole $37 \%$ of fishermen and $30.4 \%$ of community members declared that 
TAвLE 3 Bycatch rates (turtles per year), by fishing gear and region, declared by the 219 fishermen interviewed, the number of vessels by fishing gear in 2007 (source: General Fisheries Commission for the Mediterranean), and number of turtle captures per year estimated for each fishing gear from catch rates and fleet statistics.

\begin{tabular}{|c|c|c|c|c|c|}
\hline \multirow[b]{2}{*}{ Region } & \multicolumn{4}{|l|}{ Mean (SD, range, $n$ ) } & \multirow[b]{2}{*}{ Total } \\
\hline & Trawl & Longline & Purse seine & Set net & \\
\hline \multicolumn{6}{|l|}{$\begin{array}{l}\text { Catch rate (turtles per } \\
\text { fisherman-year) }\end{array}$} \\
\hline Western & $1.60(0.55,1-2,5)$ & $1.33(1.0,0-3,9)$ & & $1.89(1.05,0-3,9)$ & \\
\hline Alexandria & $1.38(0.87,0-3,13)$ & $2.11(1.28,0-4,27)$ & $0.52(0.71,0-2,25)$ & $1.70(1.10,0-4,27)$ & \\
\hline Central & $2.08(1.19,0-4,13)$ & $2.0(1.15,0-4,22)$ & $0.25(0.5,0-1,4)$ & $1.88(1.70,0-6,26)$ & \\
\hline Eastern & $1.80(1.30,0-3,5)$ & $1.60(0.84,0-3,10)$ & & $1.21(1.22,0-4,24)$ & \\
\hline Total & $1.72(1.03,0-4,36)$ & $1.90(1.16,0-4,68)$ & $0.48(0.69,0-2,29)$ & $1.64(1.35,0-6,86)$ & \\
\hline $\begin{array}{l}\text { Mediterranean fishing fleet } \\
\text { (vessels) }\end{array}$ & 1,114 & 1,095 & 207 & 1,763 & 4,179 \\
\hline $\begin{array}{l}\text { Estimated captures year }{ }^{-1} \\
\text { (inter-quartile range) }\end{array}$ & $1,916(1,114-2,228)$ & $2,081(1,095-3,285)$ & $99(0-207)$ & $3,068(1,763-3,526)$ & $\begin{array}{l}7,164 \\
(3,972-9,246)\end{array}$ \\
\hline
\end{tabular}

they consume turtle meat (Table 4), it is likely that several hundreds of turtles are slaughtered every year.

In addition to the mortality caused by intentional killing for consumption, our results suggest that there is high mortality from interactions with fishing gear. Considering that catch rates declared by fishermen might have been lower than the actual catch (and the opposite is unlikely) and that official fishery statistics may underestimate the number of fishing vessels, it is possible that the total annual number of turtles captured by the Egyptian Mediterranean fishing fleet is higher than our estimate of 7,164. Egypt is therefore a priority for marine turtle conservation in the Mediterranean. Moreover, as the Egyptian fishery mostly comprises small vessels (Seham \& Salem, 2004), our results provide additional evidence of the importance of smallscale fisheries as a threat to marine vertebrates in the Mediterranean (Godley et al., 1998; Bearzi, 2002; Casale, 2008; Karamanlidis et al., 2008).

TABLe 4 Percentage (by row) of fishermen, fishmongers and community members admitting to turtle consumption, by region and fishing community, and overall. The total number of people to which percentages refer is in parentheses beside each percentage.

\begin{tabular}{|c|c|c|c|c|}
\hline Fishing community & Fishermen \% (n) & Fishmongers \% (n) & $\begin{array}{l}\text { Community } \\
\text { members \% (n) }\end{array}$ & Total \% (n) \\
\hline \multicolumn{5}{|l|}{ Western } \\
\hline El Salum & $0.0(8)$ & & $0.0(1)$ & $0.0(9)$ \\
\hline Sidi Barani & $0.0(6)$ & $0.0(2)$ & & $0.0(8)$ \\
\hline Marsa Matruh & $0.0(9)$ & $0.0(9)$ & $0.0(2)$ & $0.0(20)$ \\
\hline El Hamam & & $0.0(2)$ & $0.0(2)$ & $0.0(4)$ \\
\hline Subtotal & $0.0(23)$ & $0.0(13)$ & $0.0(5)$ & $0.0(41)$ \\
\hline \multicolumn{5}{|l|}{ Alexandria } \\
\hline El Max & $60.9(23)$ & $33.3(9)$ & $25.0(4)$ & $50.0(36)$ \\
\hline Anfoushi & $92.9(42)$ & $68.8(16)$ & $47.4(38)$ & $70.8(96)$ \\
\hline Abou Keer & $66.7(27)$ & $33.3(12)$ & $33.3(9)$ & $52.1(48)$ \\
\hline Subtotal & $77.2(92)$ & $48.6(37)$ & $43.1(51)$ & $61.7(180)$ \\
\hline \multicolumn{5}{|l|}{ Central } \\
\hline El Maadiya & $15.4(13)$ & $0.0(6)$ & $0.0(3)$ & $9.1(22)$ \\
\hline Edco & $8.3(12)$ & $0.0(4)$ & $0.0(4)$ & $5.0(20)$ \\
\hline Rousata & $6.3(16)$ & $0.0(8)$ & $0.0(3)$ & $3.7(27)$ \\
\hline Azzbat El Borg & $0.0(14)$ & $0.0(2)$ & $0.0(2)$ & $0.0(18)$ \\
\hline Domiat & $0.0(10)$ & $0.0(7)$ & $0.0(3)$ & $0.0(20)$ \\
\hline Subtotal & $6.2(65)$ & $0.0(27)$ & $0.0(15)$ & $3.7(107)$ \\
\hline \multicolumn{5}{|l|}{ Eastern } \\
\hline Port Said & $0.0(16)$ & $12.5(8)$ & $0.0(4)$ & $3.6(28)$ \\
\hline Lake Bardawil & $25.0(12)$ & & $33.3(6)$ & $27.8(18)$ \\
\hline Areash & $27.3(11)$ & $33.3(3)$ & $36.4(11)$ & $32.0(25)$ \\
\hline Subtotal & $15.4(39)$ & $18.2(11)$ & $28.6(21)$ & $19.7(71)$ \\
\hline Total & $37.0(219)$ & $22.7(88)$ & $30.4(92)$ & $32.3(399)$ \\
\hline
\end{tabular}


Mortality of marine turtles from bottom trawling depends on tow duration. Laurent et al. (1996) reported an average tow duration of 3.1 hours for Mediterranean Egypt, which would be expected to cause high mortality of marine turtles. Sasso \& Epperly (2006) estimated a mortality rate of $<_{1} \%$ for tow durations $<_{10}$ minutes, rapidly increasing to $50-100 \%$ for tows $>60$ minutes. Mortality induced by drifting longlines has been estimated to be $>30 \%$ (Casale et al., 2008b) and mortality from bottom longlines could be even higher because this gear is anchored to the sea bottom and captured turtles may thus drown. For the same reason set nets are known to cause turtle mortality of $50 \%$ or higher (Casale et al., 2005). The interviewed fishermen reported higher turtle mortality for set nets (which are left at sea for between 8 hours and 3 days) and longlines. Hence, with a potential $50 \%$ or higher mortality rate of the estimated 3,068 captures by set nets, $30 \%$ or higher mortality rate of the estimated 2,081 captures by longliners, and a relatively low mortality of the 1,916 captures by trawlers (Table 4), it is likely that several hundred turtles die every year as a consequence of capture by fishing gear along the Mediterranean coast of Egypt.

According to the fishermen interviewed most of the turtles caught as bycatch or killed by fishermen for meat are large individuals. This is supported by fish market data (mean $64.7 \mathrm{~cm}$ curved carapace length, CCL, range 49.4$830, \mathrm{n}=16$; Laurent et al., 1996) and partially by stranding data. For stranded turtles listed by Clarke et al. (2000) the mean CCL of loggerhead turtles was $57.5 \mathrm{~cm}$ (range 11.5-124, $\mathrm{n}=38$ ) and that of green turtles was $37.4 \mathrm{~cm}$ (range $28-70$, $\mathrm{n}=8)$.

Large marine turtles have high reproductive values and are more important for population growth than small individuals (Crouse et al., 1987), and thus a high number of turtles of these sizes dying as consequence of incidental capture and intentional killing represents a serious threat to their populations. Fishermen mostly reported perceptions of negative trends in marine turtle populations and some reported that in the past they caught one turtle per week, compared to less than two turtles per year now. Reducing human-induced mortality of turtles in Egypt is therefore a high priority for the conservation of Mediterranean populations of both loggerhead and green turtles, for which Egyptian waters are an important foraging ground.

Although law enforcement provides the necessary protection context and should be improved, it is not sufficient to halt the current level of mortality from bycatch and meat consumption, and further protection measures are required. Based on our results we make four recommendations: (1) As the drivers of turtle consumption in Alexandria are cultural, intentional killing can be reduced only by changing the view of turtles as a good short-term meat resource to one as a resource to be valued and preserved for the long-term. (2) Measures to reduce capture and mortal- ity by fishing gear need to be implemented (e.g. technical modifications of fishing gears, such as turtle excluder devices or circle hooks) although this will require further research on turtle bycatch and associated factors such as fishing gear and practices. (3) Research on spatio-temporal distribution and habitat use of loggerhead and green turtles in Egyptian Mediterranean waters and on the origin of turtles frequenting these waters. (4) Protection and management of nesting sites, including monitoring of nesting activity. The results of our study are being communicated to the relevant Egyptian authorities, and specific conservation actions based on our recommendations have been designed and will be implemented when the necessary funds have been secured.

\section{Acknowledgements}

This project was funded by the Species and TRAFFIC programme of WWF Italy. We thank M. Rocco for continuous support and advice, L. Venizelos for providing relevant information, all the members of the fishing community along the Egyptian Mediterranean coast for willingly sharing their time and knowledge, the key informants for their valuable information, Amira Wafaki, Ahmed Abd Allah and Mohamed Mahmoud for their assistance with fieldwork in Alexandria, Ahmed Mahmoud for assistance in Sinai, and two anonymous referees for helpful comments. Fig. 1 was prepared with the software Maptool (from http://www.seaturtle.org).

\section{References}

BEARZI, G. (2002) Interactions between cetaceans and fisheries in the Mediterranean Sea. In Cetaceans of the Mediterranean and Black Seas: State of Knowledge and Conservation Strategies (ed. G. Notarbartolo di Sciara), pp. 9.1-9.20. ACCOBAMS, Monaco.

Broderick, A.C., Coyne, M.S., Fuller, W.J., Glen, F. \& Godley, B.J. (2007) Fidelity and overwintering of sea turtles. Proceedings of the Royal Society B, 274, 1533-1538.

Broderick, A.C., Glen, F., Godley, B.J. \& Hays, G.C. (2002) Estimating the size of nesting populations of green and loggerhead turtles in the Mediterranean. Oryx, 36, 227-236.

CAMPBell, L.M. (2003) Contemporary culture, use, and conservation of sea turtles. In The Biology of Sea Turtles, Vol. II (eds P.L. Lutz, J.A. Musick \& J. Wyneken), pp. 307-338. CRC Press, Boca Raton, USA.

Campbell, L.M., Silver, J.J., Gray, N.J., Ranger, S., Broderick, A.C., Fisher, T. et al. (2009) Co-management of sea turtle fisheries: biogeography versus geopolitics. Marine Policy, 33, 137-145.

Casale, P. (2008) Incidental Catch of Marine Turtles in the Mediterranean Sea: Captures, Mortality, Priorities. WWF Italy, Rome, Italy.

Casale, P., Freggi, D., Basso, R. \& Argano, R. (2005) Interaction of the static net fishery with loggerhead sea turtles in the Mediterranean: insights from mark-recapture data. Herpetological Journal, 15, 201-203. 
Casale, P., Freggi, D., Gratton, P., Argano, R. \& Oliverio, M. (2008a) Mitochondrial DNA reveals regional and interregional importance of the central Mediterranean African shelf for loggerhead sea turtles (Caretta caretta). Scientia Marina, 72, 541-548.

Casale, P., Freggi, D. \& Rocco, M. (2008b) Mortality induced by drifting longline hooks and branchlines in loggerhead sea turtles, estimated through observation in captivity. Aquatic Conservation: Marine and Freshwater Ecosystems, 18, 945-954.

Clarke, M., Campbell, A.C., Hameid, W.S. \& Ghoneim, S. (2000) Preliminary report on the status of marine turtle nesting populations on the Mediterranean coast of Egypt. Biological Conservation, 94, 363-371.

Cliffton, K., Cornejo, D.O. \& Felger, R.S. (1982) Sea turtles of the Pacific coast of Mexico. In Biology and Conservation of Sea Turtles (ed. K.A. Bjorndal), pp. 199-209. Smithsonian Institution Press, Washington, DC, USA.

Craw Ford, I.M. (1997) Marketing Research and Information Systems. Food and Agricultural Organization, Rome, Italy.

Crouse, D.T., Crowder, L.B. \& Caswell, H. (1987). A stage-based population model for loggerhead sea turtles and implications for conservation. Ecology, 68, 1412-1423.

Ferretti, F., Myers, R.A., Serena, F. \& Lotze, H.K. (2008) Loss of large predatory sharks from the Mediterranean Sea. Conservation Biology, 22, 952-964.

Figueroa, A., Alvarado, J., Hernandez, F., Rodriguez, G. \& Robles, J. (1992) Population Recovery of the Sea Turtles of Michoacan, Mexico: An Integrated Conservation Approach. Final Report 1991-1992 submitted to World Wildlife Fund-USA and US Fish and Wildlife Service, Washington, DC, USA.

Fleming, E.H. (2001) Swimming Against the Tide: Recent Surveys of Exploitation, Trade, and Management of Marine Turtles in the Northern Caribbean. TRAFFIC North America, Washington, DC, USA.

Frazier, J. (2003) Prehistoric and ancient historic interactions between humans and marine turtles. I. In The Biology of Sea Turtles. Volume II (eds P.L. Lutz, J.A. Musick \& J. Wyneken), pp. 1-38. CRC Press, Boca Raton, USA.

Godley, B.J., Gucu, A.C., Broderick, A.C., Furness, R.W. \& Solomon, S.E. (1998) Interaction between marine turtles and artisanal fisheries in the eastern Mediterranean: a probable cause for concern? Zoology in the Middle East, 16, 49-64.

IUCN (2010) IUCN Red List of Threatened Species v. 2010.2. Http:// www.iucnredlist.org [accessed 24 July 2010].

Karamanlidis, A.A., Androukaki, E., Adamantopoulou, S., Chatzispyrou, A., Johnson, W.M., Kotomatas, S. et al. (2008) Assessing accidental entanglement as a threat to the Mediterranean monk seal Monachus monachus. Endangered Species Research, 5, 205-213.

Kasparek, M., Godley, B.J. \& Broderick, A.C. (2001) Nesting of the green turtle, Chelonia mydas, in the Mediterranean: a review of status and conservation needs. Zoology in the Middle East, 24, 45-74.

Kelley, K., Clark, B., Brown, V. \& Sitzia, J. (2003) Good practice in the conduct and reporting of survey research. International Journal for Quality in Health Care, 15, 261-266.

Laurent, L., Abd El-Mawla, E.M., Bradai, M.N., Demirayak, F. \& Oruc, A. (1996) Reducing Sea Turtle Mortality Induced by Mediterranean Fisheries: Trawling Activity in Egypt, Tunisia and Turkey. Report for the WWF International Mediterranean Programme. WWF Project 9 E0103, Rome, Italy.

Lewison, R.L., Crowder, L.B., Read, A.J. \& Freeman, S.A. (2004) Understanding impacts of fisheries bycatch on marine megafauna. Trends in Ecology \& Evolution, 19, 598-604.
Lutcavage, M.E., Plotikin, P., Witherington, B.E. \& Lutz, P.L. (1997) Human impacts on sea turtle survival. In The Biology of Sea Turtles (eds P.L. Lutz \& J.A. Musick), pp. 387-409. CRC Press, Boca Raton, USA.

Mancini, A. \& KoCH, V. (2009) Sea turtle consumption and black market trade in Baja California Sur, Mexico. Endangered Species Research, 7, 1-10.

Margaritoulis, D., Argano, R., Baran, I., Bentivegna, F., Bradai, M.N., Caminas, J.A. et al. (2003) Loggerhead turtles in the Mediterranean Sea: present knowledge and conservation perspectives. In Loggerhead Sea Turtles (eds A.B. Bolten \& B. Witherington), pp. 175-198. Smithsonian Institution Press, Washington, DC, USA.

NAD A, M.A. (2001) Observations on the trade in sea turtles at the fish market of Alexandria, Egypt. Zoology in the Middle East, 24, 109118.

National Research Council (1990) Decline of Sea Turtles: Causes and Prevention. National Research Council, Washington, DC, USA.

Rees, A.F., Jony, M., Margaritoulis, D. \& Godley, B.J. (2008a) Satellite tracking of a green turtle Chelonia mydas from Syria further highlights importance of North Africa for Mediterranean turtles. Zoology in the Middle East, 45, 49-54.

ReEs, A.F., SAAD, A. \& Jony, M. (2008b) Discovery of a regionally important green turtle Chelonia mydas rookery in Syria. Oryx, 42, $456-459$.

S ACCHI, J. (2008) Impact des techniques de pêche sur l'environnement en Méditerranée. Études et revues. Commission Générale des Pêches pour la Méditerranée, No. 84. Food and Agricultural Organization, Rome, Italy.

SASSO, C.R. \& EPPERLY, S.P. (2006) Seasonal sea turtle mortality risk from forced submergence in bottom trawls. Fisheries Research, 81, $86-88$.

SeH AM, F.A. \& S Alem, A.M. (2004) The Present Status of Fishery and Information System in Egypt. MedFisis Technical Document No. 4.3. Food and Agricultural Organization, Rome, Italy.

Soykan, C.U., Moore, J.E., Zydelis, R., Crowder, L.B., Safina, C. \& LEWISON, R.L. (2008) Why study bycatch? An introduction to the Theme Section on fisheries bycatch. Endangered Species Research, 5, 91-102.

Tudela, S. (2004) Ecosystem Effects of Fishing in the Mediterranean: An Analysis of the Major Threats of Fishing Gear and Practices to Biodiversity and Marine Habitats. Studies and Reviews, General Fisheries Commission for the Mediterranean, No. 74. Food and Agricultural Organization, Rome, Italy.

Venizelos, L. \& Nada, M. (2000) Exploitation of loggerhead and green turtles in Egypt: good news? Marine Turtle Newsletter, 87, 12-13.

WOLD, C. (2002) The status of sea turtles under international environmental law and international environmental agreements. Journal of International Wildlife Law and Policy, 5, 11-48.

WWF (2005) WWF's Species Action Plan for the Conservation of Marine Turtles in the Mediterranean Sea. WWF Global Species Programme, Gland, Switzerland.

\section{Biographical sketches}

Mohamed Nada is manager of the Governance and Civic Engagement programme in CARE International in Egypt. He has undertaken several socio-economic and marketing research projects focusing on marine turtle conservation in Egypt. PAOLO CASALE coordinates the WWF Mediterranean sea turtle programme and the WWF Italy sea turtle project. He also conducts fundamental and applied research on marine turtle biology, ecology and bycatch in the Mediterranean. 